\title{
A Proposed Solution for Partial Shadowing
}

\author{
Mohamed Nageh \\ Researcher Assistant, Ain \\ Shams University, Cairo, Egypt \\ Teaching Assistant, American \\ University in Cairo, Egypt
}

\author{
Wagdy R. Anis \\ Professor, Department of \\ Electronics and Communication \\ Engineering, Faculty of Engineering \\ Ain Shams University, Cairo, Egypt
}

\author{
Ismail M. Hafez \\ Professor, Department of \\ Electronics and Communication \\ Engineering, Faculty of Engineering \\ Ain Shams University, Cairo, Egypt
}

\begin{abstract}
The Partial Shadowing (PS) is one of the hotspot topics and one of the significant challenges in the Photovoltaic (PV) systems. The PS of PV modules cause serious energy loss of the PV energy. It is observed (using detailed simulation MATLAB programs) that, The PS effect is clear on both of $\mathrm{I}-\mathrm{V} \& \mathrm{P}-\mathrm{V}$ output characteristics $(\mathrm{Ch} / \mathrm{s})$ curves. Also, it is observed that, the energy loss due to PS when no diode is used is significantly large. But when the diodes are used, the energy loss decreases appreciably. The saving in energy loss increases as the number of diodes per module increases. It is proposed here to increase the number of diodes per each group of solar cells results in saving of energy loss. This Paper shows the recommended number of bypass diodes (Internal or External) solution to reduce the energy loss. The internal solution by increasing of diodes number per module, while the external solution by increasing of diodes number per group. This paper also discusses the effect of increasing the operating voltage of the system on PS loss.
\end{abstract}

\section{Keywords}

Photovoltaic (PV) System, Energy Loss, Partial Shadowing (PS), Partial Shading, Shadowing Effect, Shadows, Array Configurations, Bypass Diode, Blocking Diode, Modeling and Simulation.

\section{INTRODUCTION}

The sun is the main source of all energies in the world, whatever the source is. It is a fact that, the continuous increasing of demand energy in the worldwide and the continuing decreasing of all kinds of fossil fuel, lead us to gradual dependence on the solar energy and it is different applications in our life. The solar energy has advantages and disadvantages. Its advantages are free for anyone, permanent and available at any place. Its disadvantages are not continuous irradiance (i.e. we have day and night) and it's difficult and costly to store. The previous disadvantages are major challenges in using PV source applications. Right now, let us go to study in-depth one of the hotspot topics in the PV systems; The PS problem. The PS causes significant energy loss in output of the module. The percentage of energy loss depends on the percentage of shadowing area (i.e. number of shadowed cells per module). The percentage of energy loss is generally larger than the percentage of the shadowed area of the module. In many cases the PV arrays get shadowed, completely or partly, by the passing clouds, atmosphere fluctuation, bird dropping, trees, telephone poles, towers and neighboring buildings or the shadow of one solar array on the other. This further leads to nonlinearities in characteristics. In this paper, a detailed MATLAB simulation result of a PS effect on PV array is presented. To minimize the effect of PS on the energy output of the PV array, bypass diodes are connected across each group of cells. Bypass diodes are builtin the modules to prevent energy loss when they are shaded or damaged. This paper presents a single module perform and two series modules as examples. A PV module consists of series connected cells. These cells are divided into groups where each group is bypassed by one diode or more to minimize the energy loss due to PS. The simulation results show that, as the number of bypass diodes increases, the energy loss is reduced significantly. The PS problem causes series energy loss of the PV module when all cells in PV module are connected in series (as usual). The main reason of energy loss is due to the decreased short-circuit current $\left(\mathrm{I}_{\mathrm{SC}}\right)$ of the shadowed cells. Due to the series connection of cells, the $\mathrm{I}_{\mathrm{SC}}$ of the whole series connected string drops to the value of the shadowed cells. To reduce the PS effect, bypass diodes are shunted per specified number of cells in each module. Thus, bypass diode replaces the shadowed cells. In this way the power generated by non-shadowed cells are not affected. Hence, only the power of the shadowed group is lost.

In recent years, the impact of PS on the energy yield of PV systems has been widely discussed. Many authors have tackled this problem in many papers [1]-[10]. Walker [1], the paper presents a Matlab/Simulink simulation model of PV modules. The model can be used to study the effects of parameters variations and also effect of PS on each module connected in the array. The simulation model is capable of predicting the behavior of the PV cell/module under uniform and non-uniform insolation. The variation in PV array output $\mathrm{Ch} / \mathrm{s}$ because of shading patterns and insolation variation are also shown by case studies. Walker [4], the simulation can show the effect of PS in reducing the energy obtained by a solar PV system, which should be taken in consideration during the economic evolution in the design phase. Comparison between simulated and experimental results shows that, the heuristic method is a satisfactory one. A case study with a shading effect simulation is presented to show the consequence in what concerns capturing of maximum energy, i.e. MPP tracking. Walker [5], Bypass diodes are a necessity to minimize c-Si "hot spot" damage. Therefore, if shade affects a single solar module or modules in a string or strings in an array it is important to think not in terms of cells that are shaded, but to think in terms of Bypass Diodes that are active. In conclusion, when shade affects a string there is no formula to overcome the shading de-rating. However, by combining theoretical knowledge and practical experience a responsible and satisfactory outcome for many installations that are affected by shade is possible. Walker [7], MATLAB/SIMULINK software has been developed to simulate the behavior of PV modules with different configurations under variable meteorological conditions in particular the impact of PS. The effect of the bypass diodes on $\mathrm{PV} \mathrm{Ch} / \mathrm{s}$ under PS conditions has been simulated. Experimental measurement has been done and the validity of the simulation software has been verified. Walker [8], the paper presents a Matlab/Simulink simulator model of PV cells/modules PS shaded conditions. The simulator finds the 
equivalent circuit parameters of different kind of two diodes $\mathrm{PV}$ modules model. It allows us to observe the (I-V and P-V) $\mathrm{Ch} / \mathrm{s}$ curves of any PV manufacturer modules. Conclusion, the energy production increases when the strings-bypass diodes connection is higher.

The previous works [1]-[10] discussed the PS problem and its effect on generated power only of the partially shadowed cell. Also, the variation of climatic conditions, the temperature effect, the cloudy days, the effect of change the tilt angle $(\beta)$ and the effect of increase the number of bypass diodes per module or per group; did not take into account. But there are only a few papers that actually take into account the importance of bypass diodes configuration and its number per module [5], [7] and [8]. So, the very important comparison will be presented at the end of this study to show the significantly different between the published results in [7] vs. the presented results in this paper. In this paper, more attention is given to the effect of PS on the daily and the annual energy loss of the PV array. Moreover, it is discussed the effect of PS period (from 6AM to 10AM) or (from 8AM to $12 \mathrm{PM}$ ) or (from $10 \mathrm{AM}$ to $2 \mathrm{PM}$ ) on energy loss. The conventional solution of using bypass diodes is compared with proposed solutions; (i) increasing bypass diodes per module by increasing the number of groups per module and (ii) increasing the number of bypass diodes per group of the PV module as explained in detail hereafter.

\section{SIMULATION PROGRAM DESIGN}

\subsection{Simulation MATLAB Program of Daily Energy Throughout One Year is Based on}

This section shows the results of the detailed simulation program that computes the daily energy of PV system installed in Cairo, Egypt.

\subsubsection{The climatic conditions}

The climatic conditions of Cairo, Egypt $\left(\phi=30^{\circ} \mathrm{N}\right)$ whose monthly average daily energy $\left(\mathrm{H}_{\mathrm{B}}\right)$ measured on the horizontal surface, $\beta=0^{\circ}\left(\mathrm{kWh} / \mathrm{m}^{2} /\right.$ day $)$ are given in Table 1 .

Table 1. $H_{B}$ for different months

\begin{tabular}{|c|c|c|c|c|c|c|}
\hline Month & Jan & Feb & Mar & Apr & May & Jun \\
\hline $\begin{array}{c}\mathrm{H}_{\mathrm{B}} \\
\left(\mathrm{kWh} / \mathrm{m}^{2} / \text { day }\right)\end{array}$ & 3.3 & 4.5 & 5.7 & 6.6 & 7.5 & 7.8 \\
\hline Month & Jul & Aug & Sep & Oct & Nov & Dec \\
\hline $\begin{array}{c}\mathrm{H}_{\mathrm{B}} \\
\left(\mathrm{kWh} / \mathrm{m}^{2} / \text { day }\right)\end{array}$ & 7.7 & 7.2 & 6.2 & 5.0 & 3.5 & 3.0 \\
\hline
\end{tabular}

\subsubsection{The modules used in simulation}

The modules used in simulation are five modules (connected in parallel) each module has maximum power is $P \max =200$ $\mathrm{W}$, it is maximum power voltage is $\mathrm{Vmp}=25 \mathrm{~V}$ and it is maximum power current is $\mathrm{Imp}=8 \mathrm{~A}$. So, the energy output of five modules is $(1 \mathrm{~kW})$ which required area about $\left(10 \mathrm{~m}^{2}\right)$.

\subsubsection{The temperature effect}

The temperature effect on PV array is included in the analysis. The reference cell temperature is $\mathrm{T}_{\text {Cell }}=25^{\mathrm{O}} \mathrm{C}$. As $\mathrm{T}_{\text {Cell }}$ increases, the thermal voltage $\left(\mathrm{V}_{\mathrm{T}}\right)$ increases, also the reverse saturation current (Io) increases, both of the opencircuit voltage $\left(\mathrm{V}_{\mathrm{OC}}\right)$ and the cell efficiency (Ceff) decreases.

\subsubsection{The cloudy days}

The simulation takes into consideration (14 cloudy days) throughout the year. The number of successive cloudy days in both of January and December are three days continuously (i.e. 6 days out of the 14 days during them). The other cloudy days are distributed as one cloudy day per month for February, March, April, May, September and October. For November, two successive cloudy days continuously are considered. The simulation showed that, the energy received during the cloudy day is $15 \%$ of the sunny day, (cloudy) $=0.15 \mathrm{H}_{\mathrm{B}}$ (sunny).

\subsection{Theoretical Basis}

The initial values of the simulated MATLAB program are: The tilt angle $\beta=30^{\circ}$, the latitude angle $\varphi=30^{\circ}$, the load current $\mathrm{I}_{\mathrm{L}}=1 \mathrm{~A}$, the short-circuit current $\mathrm{I}_{\mathrm{SC}}=8.27 \mathrm{~A}$, the opencircuit voltage $\mathrm{V}_{\mathrm{OC}}=33 \mathrm{~V}$, the battery voltage $\mathrm{V}_{\mathrm{B}}=25 \mathrm{~V}$, the reflectivity of the normal ground $\rho=0.2$ or $\rho=0.7$ for the snow ground.

\subsubsection{The solar declination angle $(\delta)[12]$}

$$
\delta=23.45 \sin \left[(284+\mathrm{d}) \times \frac{360}{365}\right]
$$

Where that, $d$ : Are the days of the year, $1 \leq \mathrm{d} \leq 365$

\subsubsection{The global solar radiation on the tilted surface $\left(H_{T}\right)\left(\mathrm{kWh} / \mathrm{m}^{2} /\right.$ day $)$ [12]}

$\mathrm{H}_{\mathrm{T}}=\mathrm{H}_{\mathrm{B}}\left[1.13 \mathrm{~K}_{\mathrm{T}} \mathrm{R}_{\mathrm{b}}+0.5(1+\cos \beta)\left(1-1.13 \mathrm{~K}_{\mathrm{T}}\right)+0.5 \rho(1-\cos \beta)\right]$

Where that:

$\mathrm{H}_{\mathrm{B}}$ : Monthly average daily energy, as given in Table 1.

$\mathrm{K}_{\mathrm{T}}$ : The clearness index, [12] $\mathrm{K}_{\mathrm{T}}=\frac{\mathrm{H}_{\mathrm{B}}}{\mathrm{H}_{\mathrm{ext}}}$

$\mathrm{R}_{\mathrm{b}}$ : The ratio between $\mathrm{H}_{T}$ and $\mathrm{H}_{\mathrm{B}}$, [12] $\mathrm{R}_{\mathrm{b}}=\frac{\mathrm{H}_{T}}{\mathrm{H}_{\mathrm{B}}}$

$R_{b}=1$; when $H_{T}=H_{B}$ at $\beta=0^{O}$ (On the horizontal surface).

\subsubsection{The instantaneous global solar irradiance} on the tilted surface $\left(G_{T}\right)\left(\mathrm{kW} / \mathrm{m}^{2}\right)$ [12]

$\mathrm{G}_{\mathrm{T}}=\frac{\pi}{24} \mathrm{H}_{\mathrm{T}} \frac{\cos \omega-\cos \omega_{\mathrm{s}}^{\prime \prime}}{\sin \omega_{\mathrm{s}^{\prime}}-\omega_{\mathrm{s}^{\prime}} \cos \omega_{\mathrm{s}^{\prime \prime}}}$

2.2.4 The array current $\left(\boldsymbol{I}_{\boldsymbol{A}}\right)(\mathrm{amp})$ [12]

$\mathrm{I}_{\mathrm{A}}=\mathrm{I}_{\mathrm{SC}} \mathrm{G}_{\mathrm{T}}-\mathrm{I}_{\mathrm{O}}\left(\mathrm{e}^{\left(\mathrm{V} / \mathrm{V}_{\mathrm{T}}\right)}-1\right)$

\subsubsection{The array power $\left(\boldsymbol{P}_{\boldsymbol{A}}\right)$ (watt) [12]}

$$
\mathrm{P}_{\mathrm{A}}=\mathrm{V}_{\mathrm{B}} \times \mathrm{I}_{\mathrm{A}}
$$

\subsubsection{The array energy $\left(E_{A}\right)\left(\mathrm{kWh} / \mathrm{m}^{2} /\right.$ day $)$ [12]}

$$
\mathrm{E}_{\mathrm{A}}=\mathrm{E}_{\mathrm{A}}+\left(\mathrm{P}_{\mathrm{A}} \times \Delta \mathrm{t}\right)
$$




\subsection{Flowchart}



The initial values of $(\beta, \phi, \rho, I L$, Isc and Voc)
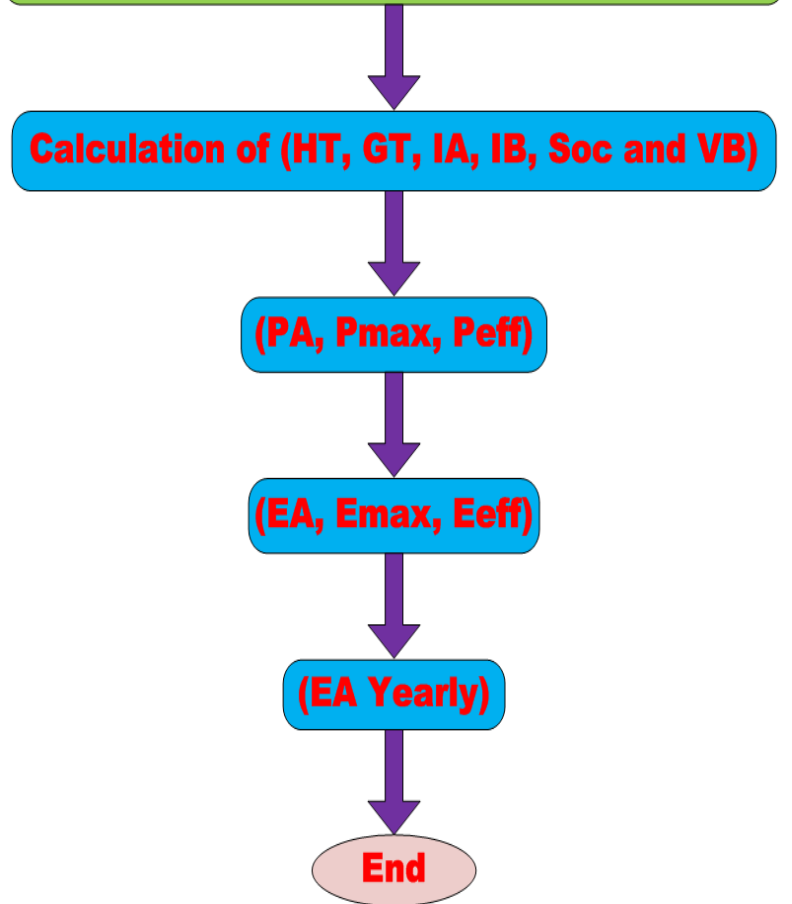

Fig 1: Flowchart of the simulated MATLAB program

\subsection{The Tilt Angle ( $\beta$ ) of The PV Array is Taken from Three Cases}

\subsection{1 $30^{\circ}$ facing south}

$30^{\circ}$ facing south (i.e. equal to latitude angle); $\beta=\phi=30^{\circ}$. This tilt angle gives maximum energy all over the year.

\subsubsection{Horizontal surface (Zero tilt angle)}

Zero degree (completely horizontal) which means, $\mathrm{H}_{\mathrm{T}}=\mathrm{H}_{\mathrm{B}}$. This has been done to check the model for the values in this case should be equal to $\mathrm{H}_{\mathrm{B}}$ that given in Table 1 .

\subsection{3 $50^{\circ}$ facing south}

$50^{\mathrm{O}}$ facing south, this value is considered suitable for the loads that needs more energy in the winter session such as the lighting systems.

Table 2. Annual average daily energy for different tilt angle

\begin{tabular}{|c|c|c|c|}
\hline Tilt angle ( $\beta)$ & $\mathbf{0}^{\mathbf{o}}$ & $\mathbf{3 0}^{\mathbf{o}}$ & $\mathbf{5 0}^{\mathbf{}}$ \\
\hline $\begin{array}{c}\text { Annual average daily } \\
\text { energy }\left(\mathrm{kWh} / \mathrm{m}^{2} / \text { day) }\right.\end{array}$ & 4.50 & 4.97 & 4.64 \\
\hline
\end{tabular}

The detailed simulation MATLAB program showed that, the monthly average daily energy depends on tilt angle $(\beta)$ as shown in (Fig 2).



Fig 2: Monthly average daily energy for different tilt angle throughout one year

It shows the optimum $(\beta)$ that gives maximum energy through one year is $\left(\beta=30^{\circ}\right)$. This curve at $\left(\beta=30^{\circ}\right)$ will be considered as a reference for illuminated array. Under shadowing effect, all results are referred to $\beta=30^{\circ}$ tilted array.

\section{ANALYSIS AND RESULTS}

\subsection{Theoretical Basis Under PS Effect}

3.1.1 The array current $\left(\boldsymbol{I}_{\boldsymbol{A}}\right)$ is given by [10]

$$
\mathrm{I}_{\mathrm{A}}=\mathrm{I}_{\mathrm{SC}} \mathrm{G}_{\mathrm{T}} \mathrm{K}-\mathrm{I}_{\mathrm{O}}\left(\mathrm{e}^{\left(\mathrm{V} / \mathrm{V}_{\mathrm{T}}\right)}-1\right)
$$

Where that, $\mathrm{K} \equiv$ Illumination Factor, $0 \leq \mathrm{K} \leq 1$ means, completely shadowed.

\subsubsection{The shadowing factor $(F)$ is given by [10]}

$$
\mathrm{F}=1-\mathrm{K}
$$

Where that, $\mathrm{F} \equiv$ Shadowing Factor, $0 \leq \mathrm{F} \leq 1$ At $\mathrm{F}=1$; that means, completely shadowed. While at $\mathrm{F}=0$; that means, fully illuminated.

\subsection{The Effect of PS}

3.2.1 The effect of PS on $(I-V \& P-V) C h / s$ curves for different shadowing rate

The detailed simulation MATLAB program shows the results indicated in the following figures. Also, Tables summarize the results of the figures.

Table 3. Power loss for different percentage of PS

\begin{tabular}{|c|c|c|c|c|c|}
\hline $\begin{array}{c}\text { Percentage of PS } \\
(\%)\end{array}$ & $\mathbf{0}$ & $\mathbf{2 5}$ & $\mathbf{5 0}$ & $\mathbf{7 5}$ & $\mathbf{1 0 0}$ \\
\hline Power loss (\%) & 0 & 27.14 & 53.41 & 78.41 & 100 \\
\hline
\end{tabular}






Fig 3: I-V $\mathrm{Ch} / \mathrm{s}$ curves for different shadowing rate



Fig 4: P-V Ch/s curves for different shadowing rate

As the percentage of PS increase, the power loss increases. So, the energy output of PV array will decrease and this is the main problem. The results show the percentage of power loss is generally larger than the percentage of the shadowed area of the module.

\subsubsection{The effect of PS on the energy loss for different shadowing rate}

Table 4. Energy loss for different shadowing rate for different shadowing periods

\begin{tabular}{|c|c|c|c|c|c|}
\hline $\begin{array}{c}\text { Percentage of PS } \\
(\%)\end{array}$ & \multirow[t]{2}{*}{ 0 } & \multirow[t]{2}{*}{25} & \multirow[t]{2}{*}{50} & \multirow[t]{2}{*}{75} & \multirow[t]{2}{*}{100} \\
\hline Energy loss (\%) at & & & & & \\
\hline $\mathrm{t}=(10 \mathrm{AM}: 2 \mathrm{PM})$ & 0 & 15.20 & 30.40 & 45.37 & 54.06 \\
\hline $\mathrm{t}=(8 \mathrm{AM}: 12 \mathrm{PM})$ & 0 & 13.16 & 26.32 & 39.19 & 45.92 \\
\hline $\mathrm{t}=(6 \mathrm{AM}: 10 \mathrm{AM})$ & 0 & 7.48 & 14.81 & 21.66 & 24.27 \\
\hline
\end{tabular}

The PS period in all cases is assumed to be four hours continuous; however, the timing is different in each case. It is clear that, the critical period is that around the noon time (from 10AM to 2PM), where the maximum solar irradiance occurs at this time. So, in this case if PS exists, the energy loss will be significant.

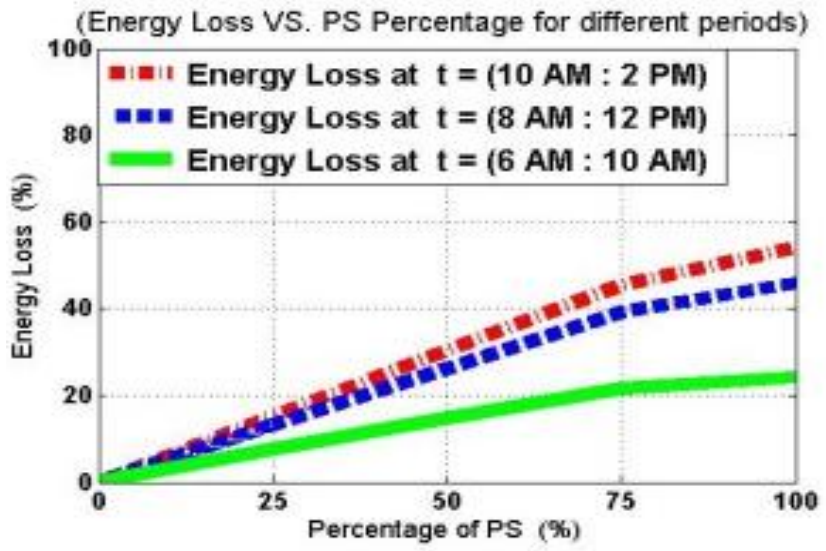

Fig 5: Energy loss for different shadowing rate for different shadowing periods

As the percentage of PS increase, the energy loss increases. As shadowing period close to the noon time, the energy loss increases. Also, as the shadowing hour's increases, the energy loss increases.

Right now, the power output during the spring equinox day where (day hours equal to night hours) from sunrise to sunset, will present as shown in (Fig 6) also the percentage energy output at the same day, will mention in Table 5.

Table 5. Energy output for different time periods of $21^{\text {st. }}$ March day and their ratio

\begin{tabular}{|c|c|c|c|}
\hline $\begin{array}{c}\text { Time period (h) } \\
\text { of 21 } \\
(\mathbf{d} \text { st. } \text { March }\end{array}$ & $\begin{array}{c}\mathbf{t}=(\mathbf{6 : 1 0}) \text { or } \\
\mathbf{t}=(\mathbf{1 4 : 1 8})\end{array}$ & $\begin{array}{c}\mathbf{t = ( 8 : 1 2 )} \text { or } \\
\mathbf{t}=(\mathbf{1 2 : 1 6})\end{array}$ & $\mathbf{t = ( 1 0 : 1 4 )}$ \\
\hline $\begin{array}{c}\text { Ratio (\%) w.r.t. } \\
\text { energy output of } \\
\text { complete day }\end{array}$ & 24.15 & 46.37 & 54.22 \\
\hline
\end{tabular}

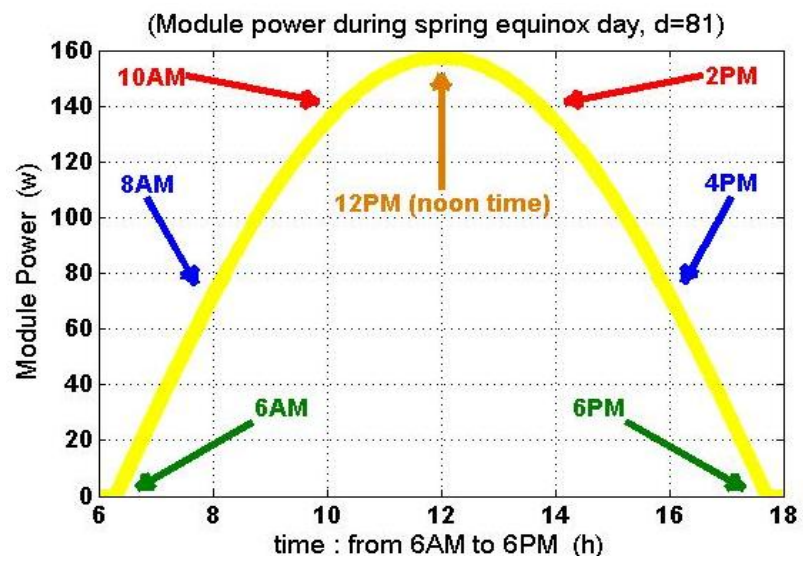

Fig 6: Power output during the spring equinox day, $d=81$

Table 1.5 shows the percentage energy output during different periods in a typical day (spring equinox $21^{\text {st. }}$ March) as an example. It is observed that, about $50 \%$ of the total daily energy takes place during the period from 10AM to $2 \mathrm{PM}$. On 
the other hand, only about $25 \%$ of the total daily energy is obtained either from 6AM to 10AM or from 2PM to 6PM.

Right now, the two alternatives (Internal and External) Diodes solutions will discuss minimizing the energy loss under the PS. The advantage of Diodes solution is independent of shadowing rate.

\subsection{Diodes Solution}

The solution of adding a parallel diode for each group of cells, overcomes the problem of current reduction due to PS. This is done by passing the real current (without shadow) through the parallel diode; hence $\mathrm{I}_{\mathrm{SC}}$ is not changed. However, the voltage across the group of cells is replaced by the voltage of the diode. Thus, the overall operating voltage is reduced. Globally, the power loss decreases as a diode is used compared with the case where no diode is used.

The simulation MATLAB programs assumed that, the period of PS (from 10AM to $2 \mathrm{PM}$ ) or (from $8 \mathrm{AM}$ to $12 \mathrm{PM}$ ) or (from $6 \mathrm{AM}$ to 10AM) it means four hours continuously of PS at each period every day during the year.

\subsubsection{The internal diodes solution (in the factory)}

a) Single Module:

1. Solution with (3 Diodes):

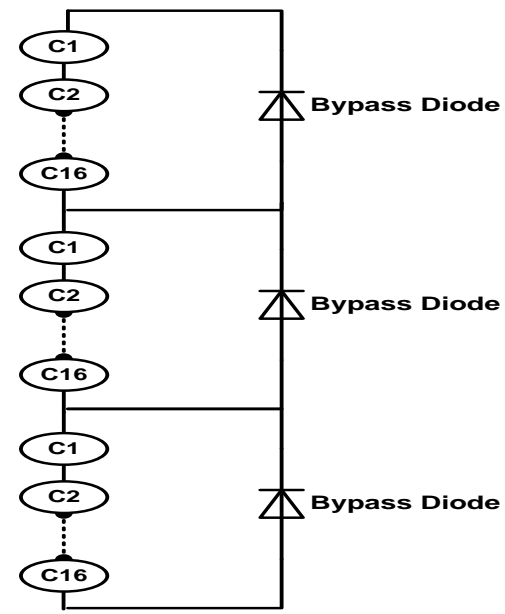

Fig 7: Solution with (3 Diodes) per module, (single diode per group)

PV modules divided the series connected cells of the module into (3 groups) and each group is consists of 16 cells are shunted by (one diode) as shown above. In case of shadowing exist in one cell (C) or more in a group. The diode voltage is $\left(\mathrm{V}_{\mathrm{D}}=0.7 \mathrm{~V}\right)$ will be instead of the overall voltage of this group. So, the energy loss will be significant. It's the problem.

Table 6. Annual average daily energy for different period of shadowing ( 3 Diodes, single module)

\begin{tabular}{|c|c|c|c|c|}
\hline $\begin{array}{c}\text { Period of } \\
\text { shadowing, } \\
\text { time (h) }\end{array}$ & $\begin{array}{c}\text { Fully } \\
\text { illuminated }\end{array}$ & $\mathbf{( 1 0 : 1 4 )}$ & $\mathbf{( 8 : 1 2 )}$ & $\mathbf{( 6 : 1 0 )}$ \\
\hline $\begin{array}{c}\text { Annual average } \\
\text { daily energy } \\
\left(\mathrm{kWh} / \mathrm{m}^{2} / \mathrm{day}\right)\end{array}$ & 4.97 & 4.17 & 4.31 & 4.70 \\
\hline
\end{tabular}

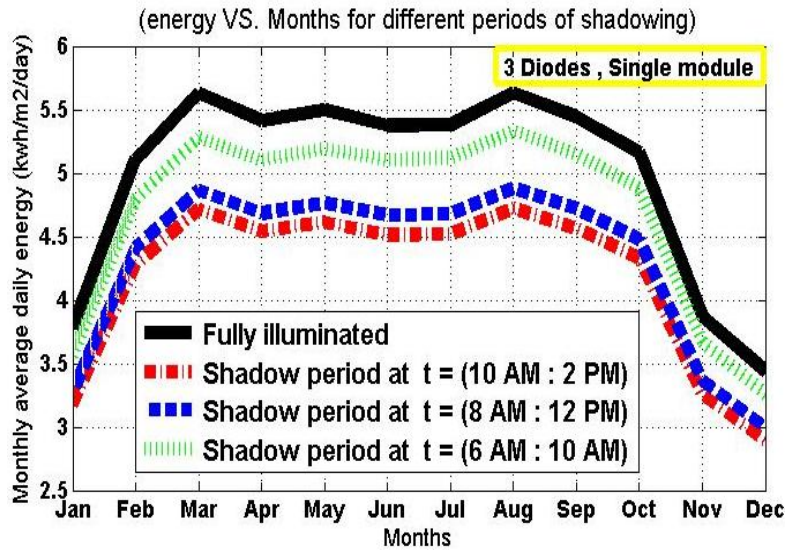

Fig 8: Monthly average daily energy with (3 Diodes) solution, (single module, single diode per group)

(Fig 8) shows the three different periods of shadowing compared with the reference curve (fully illuminated curve) Also, shows the critical period at $\mathrm{t}=(10 \mathrm{AM}: 2 \mathrm{PM})$ where the lowest energy output. While the period at $t=(6 \mathrm{AM}: 10 \mathrm{AM})$ is the highest energy output.

Right now, the effect of increasing the number of bypass diodes per the module on PS will discuss on (single module, single diode per group).

\section{Solution with (4 Diodes):}

Table 7. Annual average daily energy for different period of shadowing (4 Diodes, single module)

\begin{tabular}{|c|c|c|c|c|}
\hline $\begin{array}{c}\text { Period of } \\
\text { shadowing, } \\
\text { time (h) }\end{array}$ & $\begin{array}{c}\text { Fully } \\
\text { illuminated }\end{array}$ & $\mathbf{( 1 0 : 1 4 )}$ & $\mathbf{( 8 : 1 2 )}$ & $\mathbf{( 6 : 1 0 )}$ \\
\hline $\begin{array}{c}\text { Annual average } \\
\text { daily energy } \\
\text { (kWh/m²/day) }\end{array}$ & 4.97 & 4.40 & 4.51 & 4.81 \\
\hline
\end{tabular}



Fig 9: Monthly average daily energy with (4 Diodes) solution, (single module, single diode per group)

(Fig 9) shows the monthly average daily energy with (4 diodes) is better than ( 3 diodes), single module because increasing of the overall energy at all the shadowing periods. Due to increase in diodes numbers to be four diodes per module. 
3. Solution with (8 Diodes):

Table 8. Annual average daily energy for different period of shadowing (8 Diodes, single module)

\begin{tabular}{|c|c|c|c|c|}
\hline $\begin{array}{c}\text { Period of } \\
\text { shadowing, } \\
\text { time (h) }\end{array}$ & $\begin{array}{c}\text { Fully } \\
\text { illuminated }\end{array}$ & $\mathbf{( 1 0 : 1 4 )}$ & $\mathbf{( 8 : 1 2 )}$ & $\mathbf{( 6 : 1 0 )}$ \\
\hline $\begin{array}{c}\text { Annual average } \\
\text { daily energy } \\
\left(\mathrm{kWh} / \mathrm{m}^{2} / \text { day }\right)\end{array}$ & 4.97 & 4.75 & 4.80 & 4.97 \\
\hline
\end{tabular}

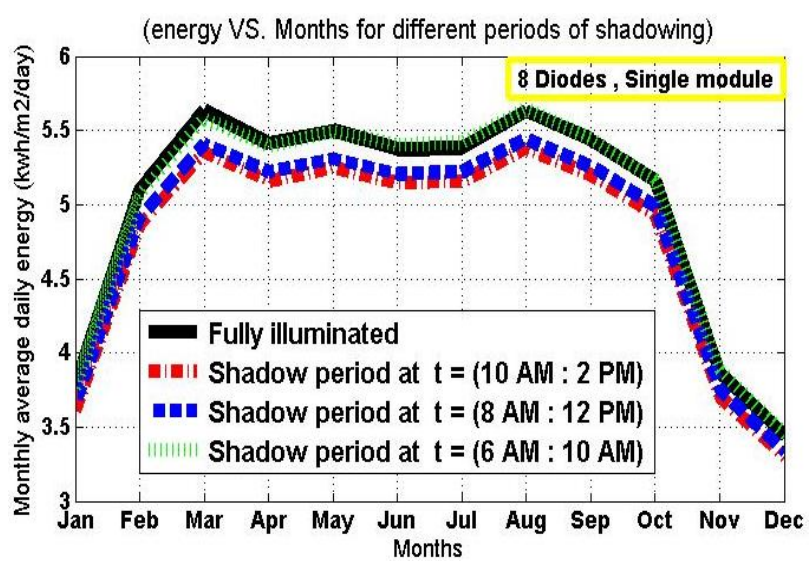

Fig 10: Monthly average daily energy with (8 Diodes) solution, (single module, single diode per group)

(Fig 10) shows the monthly average daily energy with ( 8 diodes) is the best one compared with ( 3 and 4 diodes), single module because the overall energy is close to the fully illuminated energy. From Table 8 although there is a PS (from $6 \mathrm{AM}$ to $10 \mathrm{AM}$ ) every day during the year, there is no energy loss. Due to increase of diodes numbers to be eight diodes per module.

Note that, as the number of diodes increase, the effect of PS will decrease. So, the energy output will increase. Also, the nearest curve to the fully illuminated curve is with (8 diodes). But increasing of diodes number more than eight diodes per module will be non-practical solution.

Right now, the effect of increasing the number of series modules on PS will discuss in case of (the internal solution), two series modules.

b) Two Series Modules:

1. Solution with (3 Diodes):

Table 9. Annual average daily energy for different period of shadowing (3 Diodes, two series modules)

\begin{tabular}{|c|c|c|c|c|}
\hline $\begin{array}{c}\text { Period of } \\
\text { shadowing, } \\
\text { time (h) }\end{array}$ & $\begin{array}{c}\text { Fully } \\
\text { illuminated }\end{array}$ & $\mathbf{( 1 0 : 1 4 )}$ & $\mathbf{( 8 : 1 2 )}$ & $\mathbf{( 6 : 1 0 )}$ \\
\hline $\begin{array}{c}\text { Annual average } \\
\text { daily energy } \\
\left(\mathrm{kWh} / \mathrm{m}^{2} / \text { day }\right)\end{array}$ & 10.02 & 9.24 & 9.40 & 9.86 \\
\hline
\end{tabular}

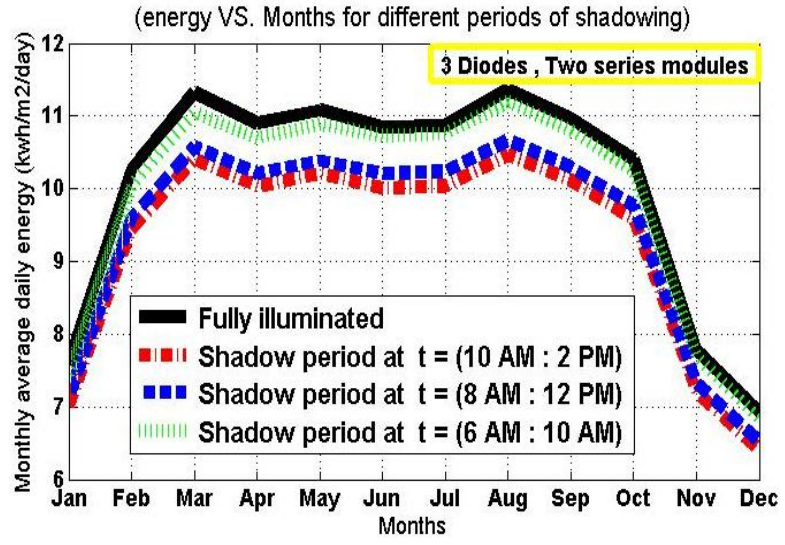

Fig 11: Monthly average daily energy with (3 Diodes) solution, (two series modules, single diode per group)

(Fig 11) shows the effect of increasing the operating voltage of the system on PS loss. It means, the overall energy at all the shadowing periods in case of (two series modules) is larger than (single module) and both of them with (3 diodes). Because, as the number of series modules increase the percentage of energy loss decrease. This is why the inverter operating voltage is large, to minimize the effect of PS.

Right now, the effect of increasing the number of bypass diodes per the module on PS will discuss on (two series modules, single diode per group).

\section{Solution with (4 Diodes):}

Table 10. Annual average daily energy for different period of shadowing (4 Diodes, two series modules)

\begin{tabular}{|c|c|c|c|c|}
\hline $\begin{array}{c}\text { Period of } \\
\text { shadowing, } \\
\text { time (h) }\end{array}$ & $\begin{array}{c}\text { Fully } \\
\text { illuminated }\end{array}$ & $\mathbf{( 1 0 : 1 4 )}$ & $\mathbf{( 8 : 1 2 )}$ & $\mathbf{( 6 : 1 0 )}$ \\
\hline $\begin{array}{c}\text { Annual average } \\
\text { daily energy } \\
\left(\mathrm{kWh} / \mathrm{m}^{2} / \text { day }\right)\end{array}$ & 10.02 & 9.47 & 9.60 & 9.96 \\
\hline
\end{tabular}

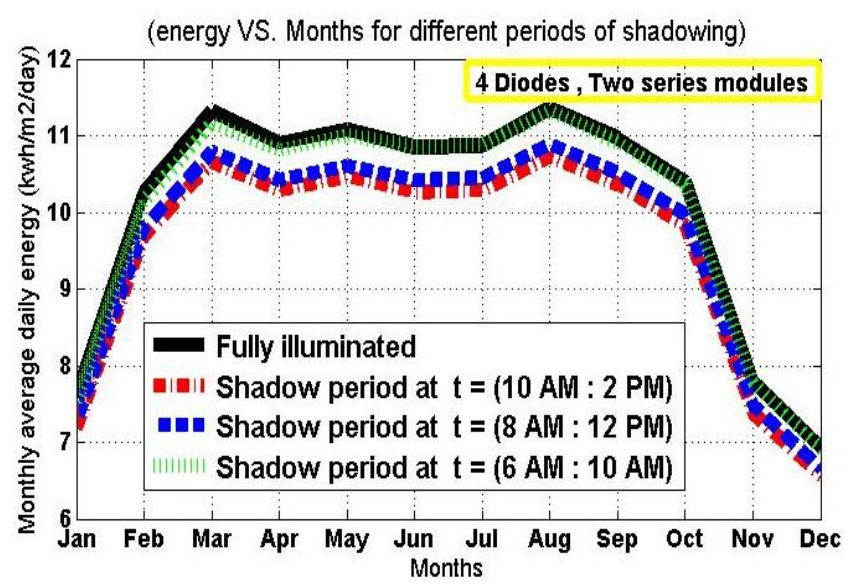

Fig 12: Monthly average daily energy with (4 Diodes) solution, (two series modules, single diode per group) 
(Fig 12) shows the monthly average daily energy with (4 diodes) is better than (3 diodes), two series modules. Also, shows (4 diodes, two series modules) are better than (4 diodes, single module).

\section{Solution with (8 Diodes):}

Table 11. Annual average daily energy for different period of shadowing (8 Diodes, two series modules)

\begin{tabular}{|c|c|c|c|c|}
\hline $\begin{array}{c}\text { Period of } \\
\text { shadowing, } \\
\text { time (h) }\end{array}$ & $\begin{array}{c}\text { Fully } \\
\text { illuminated }\end{array}$ & $\mathbf{( 1 0 : 1 4 )}$ & $\mathbf{( 8 : 1 2 )}$ & $\mathbf{( 6 : 1 0 )}$ \\
\hline $\begin{array}{c}\text { Annual average } \\
\text { daily energy } \\
\left(\mathrm{kWh} / \mathrm{m}^{2} / \text { day }\right)\end{array}$ & 10.02 & 9.82 & 9.90 & 10.13 \\
\hline
\end{tabular}



Fig 13: Monthly average daily energy with (8 Diodes) solution, (two series modules, single diode per group)

(Fig 13) shows the monthly average daily energy with ( 8 diodes) is the best one compared with ( 3 and 4 diodes), two series modules because the overall energy is close to the fully illuminated energy. From Table 11 although there is a PS (from 6AM to 10AM) every day during the year, there is no energy loss. Due to increase of diodes numbers to be eight diodes per module.

Note that, in case of ( 8 diodes, single module), the energy due to PS (from 6AM to 10AM) is equal to the fully illuminated energy as in Table 8 . While in case of (8 diodes, two series modules), the energy due to PS (from 6AM to 10AM) is greater than the fully illuminated energy as in Table 11. That means, ( 8 diodes, two series modules) is better than (8 diodes, single module).

Right now, the effect of increasing the number of bypass diodes per group will discuss. This solution is called the external solution where anyone can improve the performance under PS by increasing the number of bypass diodes per group. External diodes are connected in the external box (junction box) of the module. The principle is to increase the operating voltage of the module under the PS.

\subsubsection{The external diodes solution}

a) Single Module:

1. Solution with (3 Groups):

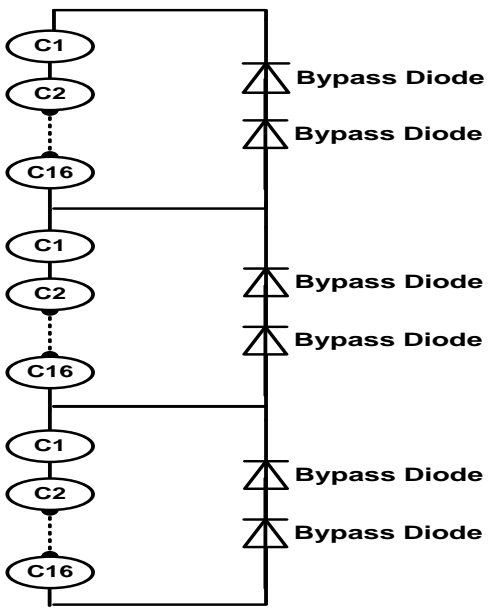

Fig 14: Solution with (3 Groups) per module, (two diodes per group); ( 3 internal diodes) plus ( 3 external diodes)

PV modules divided the series connected cells of the module into (3 groups) and each group is consists of 16 cells are shunted by (two diodes) i.e. one internal and another external as shown above. In case of shadowing exist in one cell (C) or more in a group. The diode voltage is $\left(\mathrm{V}_{\mathrm{D}}=0.7 \mathrm{~V} \times 2=1.4 \mathrm{~V}\right)$ will be instead of the overall voltage of this group. So, the energy loss of the external solution will be less than the energy loss of the internal solution, due to increase of one bypass diode per each group externally.

Table 12. Annual average daily energy for different number of diodes per group ( 3 Groups, single module)

\begin{tabular}{|c|c|c|c|}
\hline $\begin{array}{c}\text { Number of diodes } \\
\text { per group }\end{array}$ & $\begin{array}{c}\text { Fully } \\
\text { illuminated }\end{array}$ & Single & Two \\
\hline $\begin{array}{c}\text { Annual average daily } \\
\text { energy }\left(\mathrm{kWh} / \mathrm{m}^{2} / \text { day }\right)\end{array}$ & 4.97 & 4.17 & 4.25 \\
\hline
\end{tabular}

Table 12. The PS (from 10AM to 2PM) it means four hours continuously of PS every day during the year.

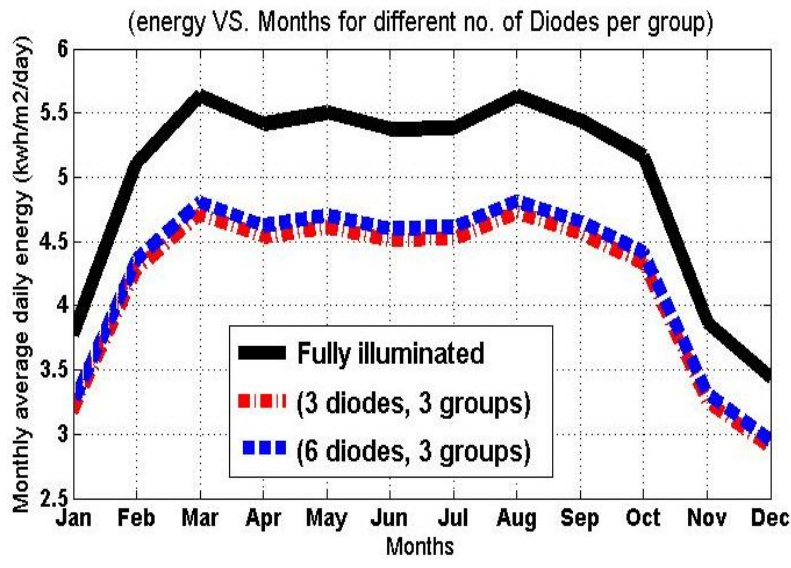

Fig 15: Monthly average daily energy with (3 groups) solution, $t=(10 A M: 2 P M),($ single module $)$ 
(Fig 15) shows the effect of adding ( 3 external diodes) plus (3 internal diodes) which means, two diodes per group. So, the overall energy with (3 groups, two diodes per group) is better than (3 groups, single diode per group) - single module. The results of increasing the number of bypass diodes per group (Externally) are demonstrated for the case of three groups only per module. However, same analysis is valid for other number of groups.

Note that, the effect of increasing the diodes number per module (Internally) is more efficient than increasing the diodes number per group (Externally). Because, internally; the number of cells per diode decrease so, the effect of PS decrease significantly. While externally; just only the number of diodes increases on the same number of cells so, the effect of PS decreases very little.

\subsection{The Gain Between (Single \& Two Diodes) Per Group}

3.4.1 The gain in case of (3 groups only) [10]

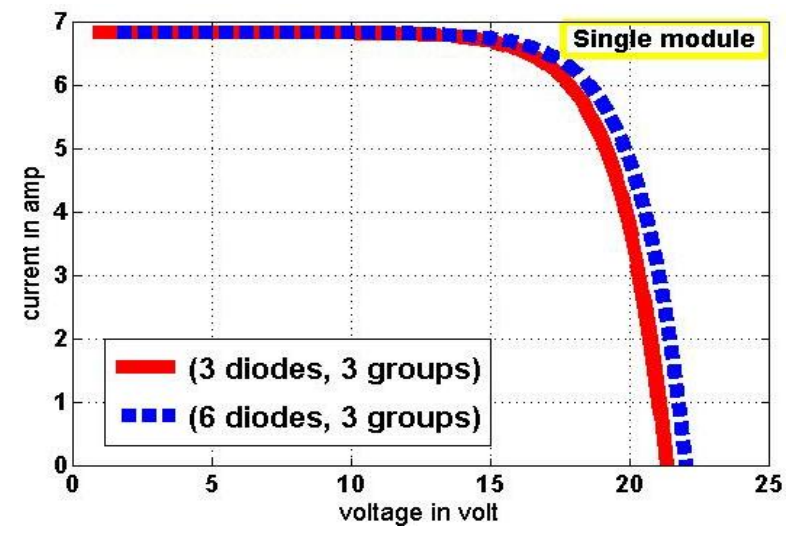

Fig 16: I-V Ch/s curves for (single \& two diodes) per group

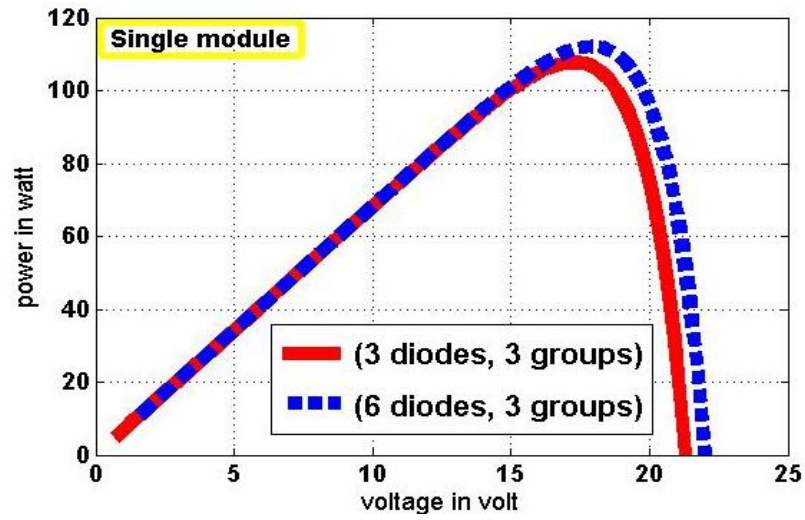

Fig 17: P-V Ch/s curves for (single \& two diodes) per group

Gain $(\%)=\left(\frac{V_{2} I_{2}-V_{1} I_{1}}{V_{1} I_{1}}\right) \times 100$

The gain of ( 3 groups only) $=5.47 \%$ (extra energy). This is the energy gain due to addition of one external bypass diode per group as shown in the figures above.
As the number of diodes per group increases, module operating voltage increase, maximum power point tracking (MPPT) increases, power and energy output increases, energy loss decreases. So, the effect of PS will minimize significantly.

\subsection{The Effect of Increasing The Diodes Number}

\subsubsection{The effect of increasing the diodes number per module on $(I-V \& P-V) C h / s$ curves}

Table 13. Power loss for different number of diodes per module

\begin{tabular}{|c|c|c|c|c|c|}
\hline $\begin{array}{c}\text { Number of } \\
\text { diodes per } \\
\text { module }\end{array}$ & $\begin{array}{c}\text { Fully } \\
\text { illuminated }\end{array}$ & $\mathbf{3}$ & $\mathbf{4}$ & $\mathbf{8}$ & $\mathbf{1 2}$ \\
\hline $\begin{array}{c}\text { Power loss } \\
(\%)\end{array}$ & Zero & 30.53 & 22.20 & 9.70 & 5.53 \\
\hline
\end{tabular}

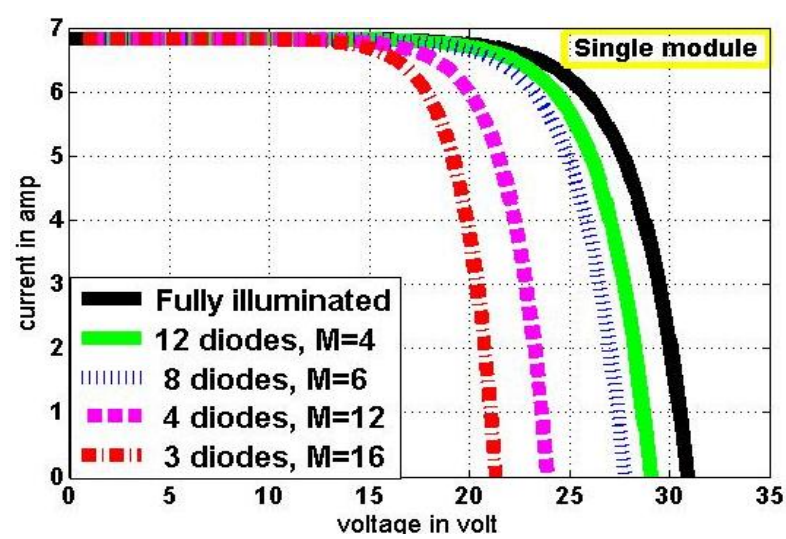

Fig 18: I-V Ch/s curves for different diodes number

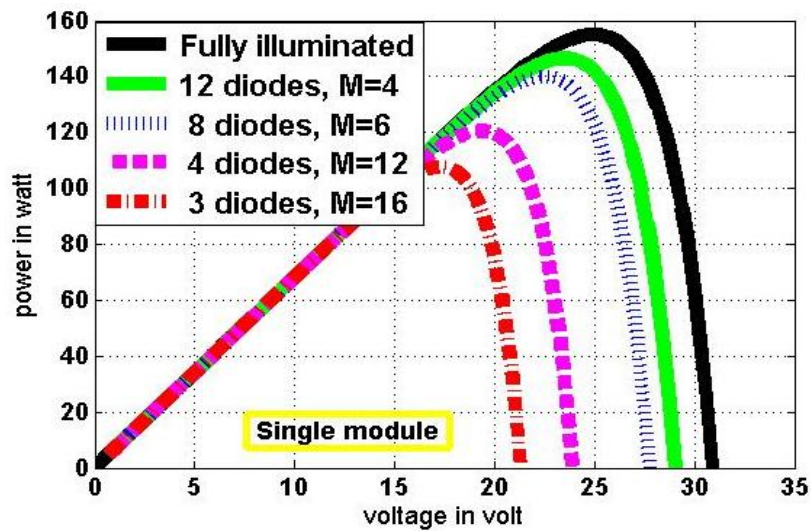

Fig 19: P-V Ch/s curves for different diodes number

As the number of diodes per module increase, the power loss decreases. So, the energy output of PV array increases, because the effect of PS minimized as much as possible. 


\subsubsection{The effect of increasing the diodes number per module on the energy loss for different shadowing periods}

Table 14. Energy loss for different diodes number per module for different shadowing periods

\begin{tabular}{|c|c|c|c|c|c|}
\hline Diodes number & $\begin{array}{c}\text { Fully } \\
\text { illumin } \\
\text { Energy loss (\%) at }\end{array}$ & $\mathbf{3}$ & $\mathbf{4}$ & $\mathbf{8}$ & $\mathbf{1 2}$ \\
\cline { 1 - 5 } $\mathrm{t}=(10 \mathrm{AM}: 2 \mathrm{PM})$ & Zero & 17.02 & 12.53 & 5.76 & 3.37 \\
\hline $\mathrm{t}=(8 \mathrm{AM}: 12 \mathrm{PM})$ & Zero & 14.62 & 10.78 & 4.93 & 2.88 \\
\hline $\mathrm{t}=(6 \mathrm{AM}: 10 \mathrm{AM})$ & Zero & 8.14 & 6.04 & 2.77 & 1.58 \\
\hline
\end{tabular}

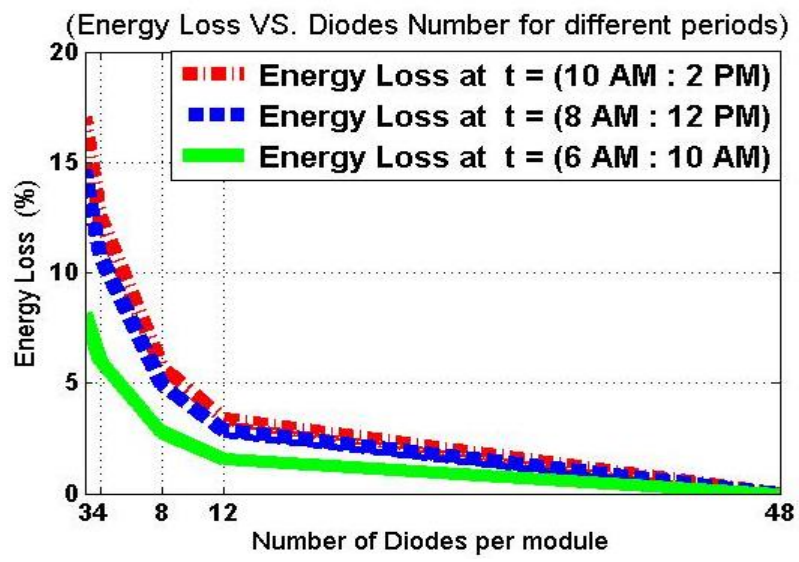

Fig 20: Energy loss for different diodes number per module for different shadowing periods

As the number of diodes increase, the energy loss due to PS decreases. As the shadowing period goes far from the noon time the energy loss decreases. Also, as the shadowing hours decrease, the energy loss decreases.

Finally, "A Proposed Solution for Partial Shadowing", is presented.

\section{COMPARATIVE RESULTS}

\subsection{Comparison Between Simulation and} Practical Measurements

Table 15. Annual average daily energy for simulation and practical measurements

\begin{tabular}{|c|c|c|}
\hline Measurements & Simulation & Practical \\
\hline $\begin{array}{c}\text { Annual average daily } \\
\text { energy }\left(\mathrm{kWh} / \mathrm{m}^{2} / \text { day }\right)\end{array}$ & 4.98 & 4.74 \\
\hline
\end{tabular}

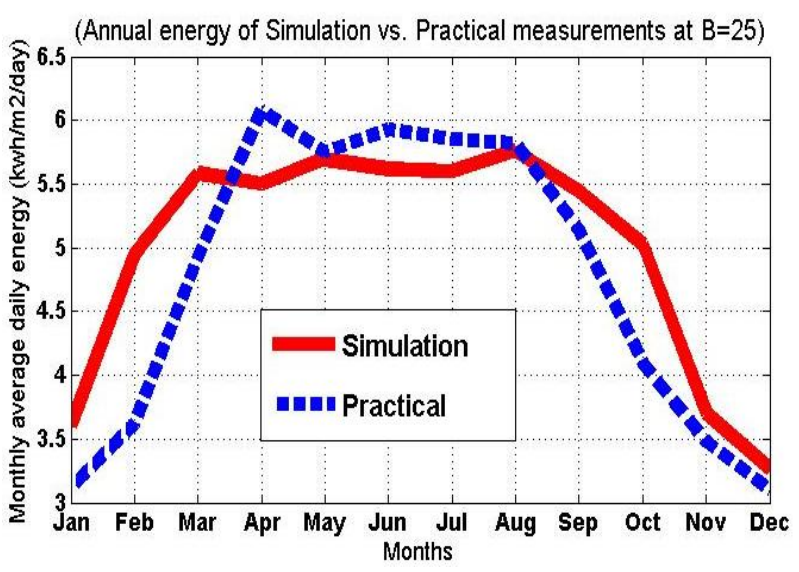

Fig 21: Monthly average daily energy for simulation and practical measurements

The difference between simulation and practical measurements is $(4.98 / 4.74)-1=0.05 \%$; this is a very small difference between them during the year, it can be neglected. So, all of the presented results in this Paper are done.

\subsection{Comparison Between The Published Results in [7] vs. The Presented Results in This Paper}

In this section, a complete comparison between the published results in [7] vs. the presented results in this paper will be presented in Table 16

\section{CONCLUSION}

In fact, the ideal solution of the PS problem is (one diode for each cell). But this solution requires more interconnections to have terminals inside the module to connect the diodes and add some extra cost and weight to the module. On other side embedding the diodes in the encapsulation material is technologically not implemented yet. So, this paper presents two alternative solutions. The first one is by increasing the bypass diodes number per module (Internally). The second one is proposed to increase the bypass diodes number per group (Externally).

\section{ACKNOWLEDGEMENTS}

The author would like to thank Professor Wagdy R. Anis, Department of Electronics and Communication Engineering, Faculty of Engineering Ain Shams University, Cairo, Egypt; for great helping and continuous support during this research point.

The author would like to thank Professor Abdelhalim Zekry, Department of Electronics and Communication Engineering, Faculty of Engineering Ain Shams University, Cairo, Egypt; for previewing this research. 
Table 16. The published results in [7] vs. the presented results in this paper

\begin{tabular}{|c|c|c|}
\hline $\begin{array}{c}\text { Face } \\
\text { comparison }\end{array}$ & Published results & Presented results \\
\hline Paper title & $\begin{array}{l}\text { Partial Shadowing of PV System } \\
\text { Simulation with Experimental Results }\end{array}$ & A Proposed Solution for Partial Shadowing \\
\hline $\begin{array}{c}\text { Module } \\
\text { specifications }\end{array}$ & $\begin{array}{c}P \max =140 \mathrm{~W}, \mathrm{Vmp}=17.7 \mathrm{~V}, \operatorname{Imp}=7.91 \mathrm{~A} \\
\text { Voc }=22.1 \mathrm{~V}, \mathrm{Isc}=8.68 \mathrm{~A}\end{array}$ & $\begin{array}{c}\operatorname{Pmax}=200 \mathrm{~W}, \mathrm{Vmp}=25 \mathrm{~V}, \operatorname{Imp}=8 \mathrm{~A}, \\
\text { Voc }=33 \mathrm{~V}, \text { Isc }=8.27 \mathrm{~A}\end{array}$ \\
\hline $\begin{array}{l}\text { Number of cells } \\
\text { per module }\end{array}$ & $\begin{array}{l}36 \text { cells (series connected), } \\
\text { Polycrystalline Cell technology. }\end{array}$ & $\begin{array}{l}48 \text { cells (series connected), } \\
\text { Polycrystalline Cell technology. }\end{array}$ \\
\hline $\begin{array}{l}\text { Number of } \\
\text { bypass diodes } \\
\text { per module }\end{array}$ & $\begin{array}{l}\text { Limited to two bypass diodes per module } \\
\text { (Internally only). The module is divided } \\
\text { into two groups, each group has } 18 \text { cells are } \\
\text { connected to one bypass diode. So, the } \\
\text { performance of PV array will be limited. }\end{array}$ & $\begin{array}{c}\text { The numbers of bypass diodes are increasing in this paper to be } \\
3 \text { or } 4 \text { or } 8 \text { per module (Internally). The module is divided into } 3 \\
\text { or } 4 \text { or } 8 \text { groups, each group has } 16 \text { or } 12 \text { or } 6 \text { cells respectively } \\
\text { are connected to one bypass diode. So, the performance of PV } \\
\text { array will be increasing significantly than the published results } \\
\text { in paper [7]. In addition, of increasing the number of } \\
\text { bypass diodes per group (Externally). }\end{array}$ \\
\hline $\begin{array}{l}\text { Module design } \\
\text { complexity }\end{array}$ & $\begin{array}{l}\text { Module design complexity is affordable } \\
\text { w.r.t. the number of bypass diodes } \\
\text { per module. }\end{array}$ & $\begin{array}{l}\text { Module design complexity is increased due to increase of the } \\
\text { number of bypass diodes (Internally or Externally). } \\
\text { So, some more interconnections are needed. }\end{array}$ \\
\hline $\begin{array}{l}\text { MATLAB } \\
\text { Programs used } \\
\text { in simulation }\end{array}$ & $\begin{array}{l}\text { Just only MATLAB/SIMULINK } \\
\text { software has been developed, } \\
\text { ready-made software. }\end{array}$ & $\begin{array}{l}\text { All the presented results via a completely handmade MATLAB } \\
\text { programs with fully flexible features. In these programs, } \\
\text { any condition or parameter can change/modify easily. }\end{array}$ \\
\hline $\begin{array}{l}\text { Simulation work } \\
\text { done }\end{array}$ & $\begin{array}{l}\text { Simulation work is done on single module } \\
\text { and two series modules. }\end{array}$ & $\begin{array}{l}\text { Simulation work is done on single module } \\
\text { and two series modules. }\end{array}$ \\
\hline $\begin{array}{l}\text { Experimental } \\
\text { results }\end{array}$ & $\begin{array}{l}\text { Experimental measurement has been done } \\
\text { and the validity of the simulation software } \\
\text { has been verified. }\end{array}$ & $\begin{array}{l}\text { The presented results are based on MATLAB simulation } \\
\text { programs whose results are compared with practical } \\
\text { measurements throughout one complete year. } \\
\text { Very good agreement is observed between } \\
\text { simulation and practical measurements. }\end{array}$ \\
\hline $\begin{array}{l}\text { Results } \\
\text { limitations }\end{array}$ & $\begin{array}{l}\text { Limited to study only I-V \& P-V Ch/s } \\
\text { curves under different patterns of PS } \\
\text { effects. Also, these results at } \\
\text { a moment in a day. }\end{array}$ & $\begin{array}{l}\text { The simulated MATLAB programs have been studied the I-V \& } \\
\text { P-V Ch/s curves under different percentage of PS. Then, } \\
\text { calculated the power and energy loss under both of different } \\
\text { percentage of PS and different shadowing periods. } \\
\text { After that, calculated the daily, monthly and yearly energy } \\
\text { output of PV array in case of fully illuminated to be as a } \\
\text { reference. Then, calculated the yearly energy output under } \\
\text { different shadowing periods every day during a year. These } \\
\text { calculations are done with } 3 \text { or } 4 \text { or } 8 \text { bypass diodes per module } \\
\text { (Internally) on single module and two series modules. } \\
\text { After that, these calculations are done with increasing of the } \\
\text { number of bypass diodes per group (Externally) on single } \\
\text { module and two series modules. Then, calculated the energy } \\
\text { gain between (single and two diodes) per group. } \\
\text { Finally, The simulated MATLAB programs have been studied } \\
\text { the I-V \& P-V Ch/s curves again with increasing the number of } \\
\text { bypass diodes per module (Internally). Then, calculated the } \\
\text { power and energy loss with both of increasing the number of } \\
\text { bypass diodes and different shadowing periods. }\end{array}$ \\
\hline
\end{tabular}




\section{REFERENCES}

[1] Smita Pareek and Ratna Dahiya. 2015,"Simulation and Performance Analysis of Individual Module to Address Partial Shading cum Parameter Variation in Large Photovoltaic Fields", Vol. 2, No. 3, 2015, pp. 99-104.

[2] SWAPNIL BORADE and MR. G. K. MAHAJAN. 2015, "MPPT Controller under Partial Shading Condition", E-ISSN: 2348-0831 Volume 2, Issue 3 (MAR-APR 2015) PP 56-60.

[3] JianboBai, Yang Cao, YuzheHao, Zhen Zhang, Sheng Liu and Fei Cao. 2015,"Characteristic output of PV systems under partial shading or mismatch conditions", Solar Energy $11241-54$.

[4] L. Fialho, R. Melicio, V.M.F. Mendes, J. Figueiredo and M. Collares-Pereira. 2014,"Effect of Shading on Series Solar Modules: Simulation and Experimental Results", Procedia Technology 17 (2014) 295 - 302.

[5] Peter Bulanyi and Rodd Zhang. 2014,"Shading Analysis \& Improvement for Distributed Residential GridConnected Photovoltaics Systems", Solar 2014.

[6] Younis Khalaf, Osama Ibraheem, Mustafa Adil, Salih Mohammed, Mohammed Qasim and Khaled Waleed. 2014,"Maximum Power Point Evaluation of Photovoltaic
Modules Under Shading Effect", European Scientific Journal March 2014 edition vol.10, No.9 ISSN: 1857 7881 (Print) e - ISSN 1857- 7431.

[7] Basim A. Alsayid, Samer Y. Alsadi, Ja'far S. Jallad and Muhammad H. Dradi. 2013,"Partial Shading of PV System Simulation with Experimental Results", Smart Grid and Renewable Energy. 4, 429-435.

[8] N. Belhaouas, M.S. Ait Cheikh, A. Malek and C. Larbes. 2013,"Matlab-Simulink of photovoltaic system based on a two-diode model simulator with shaded solar cells",Revue des Energies Renouvelables Vol. $16 \mathrm{~N}^{\circ} 1$ (2013) $65-73$.

[9] Ajay Patel, Vikas Kumar and Yogendra Kumar. 2013, "Perturb and Observe Maximum Power Point Tracking for Photovoltaic Cell”, Vol.4, No.6, 2013.

[10] Anis, Wagdy R. 1989,"Partial Shadowing Protection without Diodes", Solar cells, 26 () 227 - 239.

[11] Tiwari, Gopal Nath and Swapnil Dubey. 2010, "Fundamentals of photovoltaic modules and their applications", No. 2 Royal Society of Chemistry.

[12] Anis Wagdy R. 1985,'Design of photovoltaic systems for tropical climates", Ph.D. thesis, catholic university of loavain, Belgium, Solar cells15, no. 1. 